\title{
Analisis Pengendalian Persediaan Bahan Baku Rotan terhadap Kelancaran Proses Produksi pada CV. Home Fashions Indonesia Cirebon
}

\author{
Citra Agustin Putri ${ }^{1}$; Dida Farida Latipatul Hamdah²; Cecep Hamzah Pansuri ${ }^{3}$ \\ ${ }^{1}$ Universitas Garut \\ 24022115107@fekon.uniga.ac.id \\ ${ }^{2}$ Universitas Garut \\ didafaridalh@uniga.ac.id \\ ${ }^{3}$ Universitas Garut \\ cecephamzah@uniga.ac.id
}

\begin{abstract}
Abstrak
Tujuan dari penelitian ini adalah untuk mengetahui bagaimana pengendalian persediaan bahan baku dan kelancaran proses produksi dengan menggunakan metode Economic Order Quantity pada CV. Home Fashions Indonesia Cirebon. Metode penelitian ini menggunakan data kualitatif. Pengolahan data secara kualitatif ini digunakan untuk mengolah data berupa rencana dan realisasi kuantitas bahan baku rotan untuk pembutan keranjang dari tahun 2014 sampai dengan tahun 2018. Hasil yang diperoleh menunjukkan bahwa metode Economic Order Quantity dapat membantu perusahaan untuk menentukan jumlah pembelian yang paling ekonomis dan dapat menentukan frekuensi pembelian yang konstan, serta menentukan titik pemesanan kembali dengan persediaan pengaman secara tepat untuk menunjang kelancaran proses produksi pada perusahaan.
\end{abstract}

Kata kunci: Economic Order Quantity, Kelancaran Proses Produksi, Pengendalian Persediaan Bahan Baku.

\begin{abstract}
The purpose of this study is to find out how to control the supply of raw materials and the smooth production process using the Economic Order Quantity method on CV. Home Fashions Indonesia Cirebon. The research method use qualitative data. The qualitative data processing is used to process data in the form of plans and the realization of the the quantity of rattan raw materials for bucket making from 2014 to 2018. The results obtained show that the Economic Order Quantity method can help companies to determine the most economical purchase amount and can determine the frequency of constant purchases, as well as determine the point of reordering with a safety inventory appropriately to support the smooth production process at the company.
\end{abstract}

Keywords: Economic Order Quantity, Raw Material Inventory Control, Smooth Production Process 


\section{Pendahuluan}

Perkembangan pembangunan perekonomian Indonesia saat ini merupakan aspek yang harus merata. Pembangunan usaha kecil maupun usaha besar merupakan suatu keberhasilan suatu negara dalam bidang ekonomi. Dalam hal ini masyarakat yang berjiwa wirausaha merupakan suatu aset yang penting dalam pembangunan perekonomian. Kemajuan teknologi dan ilmu pengetahuan saat ini menuntut perusahaan untuk lebih kompetitif dalam bersaing dengan perusahaan lain untuk merebut pasar yang ada. Perusahaan harus mampu mempertahankan kredibilitas yang dimiliki, agar perusahaan tidak mengalami dampak yang buruk.

Setiap perusahaan baik itu perusahaan jasa maupun perusahaan manufaktur mempunyai tujuan yang sama yaitu ingin mendapatkan keuntungan yang maksimal. Untuk mencapai tujuan tersebut dalam perusahaan manufaktur tidak mudah, hal itu dipengaruhi oleh beberapa faktor, salah satu faktornya yaitu masalah kelancaran produksi. Dalam perusahaan yang bergerak di bidang manufaktur, seperti industri yang berbahan baku rotan sangat perlu direncanakan agar persediaan tetap tersedia dan tidak terjadi kekurangan atau kelebihan. Dalam industri rotan ketersediaan bahan baku sangat dipengaruhi oleh beberapa faktor antara lain sumber daya alam, dan sumber daya manusia. Kedua faktor tersebut saling berkaitan dalam ketersediaannya bahan baku rotan. Dengan tersedianya sumber daya alam yang melimpah tanpa dibarengi dengan sumber daya manusia yang cukup dan profesional maka akan terjadi ketidakseimbangan dalam penyediaan bahan baku rotan sehingga akan menghambat proses produksi.

CV. Home Fashions Indonesia Cirebon adalah salah satu perusahaan swasta yang bergerak dalam bidang industri furniture dan kerajinan dari rotan, kayu, anyaman di daerah Cirebon yang mana hasil produksinya diekspor ke Luar Negeri. Adapun data pembelian bahan baku menunjukkan bahwa pada tahun 2014 mengalami stock out yang dibutuhkan sebanyak $95.328 \mathrm{~kg}$ tetapi yang tersedia hanya $95.297 \mathrm{~kg}$, tetapi pada tahun 2015 terjadi kelebihan bahan baku $207 \mathrm{~kg}$ yang dibutuhkan $104.988 \mathrm{~kg}$, yang tersedia $105.195 \mathrm{~kg}$. Pada tahun 2016-2017 mengalami kembali stock out atau kekurangan bahan baku, yang dibutuhkan $112.390 \mathrm{~kg}, 114.675 \mathrm{~kg}$, bahan baku yang tersedia hanya $110.125 \mathrm{~kg}, 113.100 \mathrm{~kg}$, sedangkan pada tahun 2018 mengalami kelebihan bahan baku sebanyak $425 \mathrm{~kg}$.

Dengan demikian fenomena dalam penelitian ini adalah CV. Home Fashions Indonesia Cirebon mengalami kekurangan persediaan bahan baku pada tahun 2014, 2016, 2017, hal tersebut dikarenakan naiknya harga bahan baku rotan tetapi tidak bisa menaikan harga jual produk, sehingga permintaan konsumen sedikit tidak terpenuhi.

\section{Tinjauan Pustaka}

Menurut Handoko (2012) Persediaan merupakan istilah untuk menunjukkan sumber daya yang dimiliki suatu organisasi untuk memenuhi permintaan baik internal maupun eksternal. Menurut Heizer dan Render (2017) fungsi persediaan adalah sebagai berikut:

1. Untuk memberikan pilihan barang agar dapat memenuhi permintaan pelanggan yang diantisipasi dan memisahkan perusahaan dari fluktuasi permintaan. Persediaan ini digunakan secara umum pada perusahaan ritel.

2. Untuk memisahkan beberapa tahapan dari proses produksi, seperti apabila persediaan suatu perusahaan berfluktuasi, persediaan tambahan mungkin diperlukan agar bisa memisahkan proses produksi dari pemasok. 
3. Untuk mengambil keuntungan dari potongan jumlah karena pembelian dalam jumlah besar dapat menurunkan biaya pengiriman barang.

4. Untuk menghindari inflasi dan kenaikan harga.

Setiap perusahaan pasti menginginkan perusahaannya berjalan dengan lancar dan mendapatkan laba yang diinginkan. Seperti halnya di dalam perusahaan manufaktur yang mendambakan bahwa kegiatan produksi terus berjalan, menghasilkan produk dengan tepat waktu, dan menekan biaya dalam proses produksi. Maka dari itu ada salah satu metode yang dapat digunakan untuk pengendalian persediaan bahan baku dan untuk mencapai hal tersebut, yaitu metode Economic Order Quantity.

Adapun menurut Heizer dan Render (2017) beberapa kebijakan Economic Order Quantity untuk menjamin kelancaran kegiatan produksi dan biaya yang digunakan oleh perusahaan seminimal mungkin, diantaranya:

a) Menentukan jumlah pemesanan yang optimal dan ekonomis

Rumus yang digunakan untuk menghitung Economic Order Quantity, yaitu:

$$
\mathrm{EOQ}=\sqrt{\frac{2(D)(S)}{H}}
$$

Keterangan:

EOQ = Jumlah unit pesanan yang optimal

$\mathrm{D} \quad=$ Permintaan tahunan (demand)

$\mathrm{S} \quad=$ Biaya pemesanan

$\mathrm{H}$ = Biaya penyimpanan

b) Periode pemesanan (Frekuensi)

Dalam kegiatan produksi tentunya harus dipersiapkan atau ditentukan berapa kali pemesanan bahan baku yang dilakukan dalam setiap periode nya atau tiap tahunnya. Berikut adalah rumus untuk menghitung jumlah berapa kali pemesanan pada setiap periode:

$$
\mathrm{I}=\frac{D}{E O Q}
$$

Keterangan:

I = Periode pemesanan (Frekuensi)

$\mathrm{D} \quad=$ Jumlah permintaan

EOQ $=$ Jumlah pesanan yang optimal dan ekonomis

c) Total Biaya Persediaan

Total biaya persediaan merupakan biaya pemesanan dan biaya penyimpanan.

Berikut rumus yang digunakan untuk menghitung total biaya persediaan:

Total Cost $=$ Biaya Pemesanan + Biaya Penyimpanan

d) Waktu Tunggu (Lead Time)

Waktu tunggu yaitu selisih antara penempatan pesanan dan penerimaannya. Waktu tunggu terjadi hanya dalam beberapa jam, hari, atau juga mencapai bulan.

e) Titik Pemesanan Kembali (Reorder Point) dengan Persediaan Pengaman (Safety Stock) 
Reorder point merupakan suatu tingkat persediaan dimana tindakan diambil untuk mengisi persediaan barang yang telah habis.

Untuk menentukan pemesanan kembali dapat menggunakan rumus sebagai berikut:

$$
\mathrm{ROP}=(\mathrm{d} \times \mathrm{L})
$$

Keterangan:

ROP $=$ Pemesanan kembali

$\mathrm{d} \quad=$ Jumlah rata-rata per hari

$\mathrm{L} \quad=$ Lead Time

Persamaan ini berasumsi bahwa permintaan selama waktu tunggu dan waktu tunggu itu tidak berubah. Sedangkan apabila kasusnya berbeda, maka persediaan pengaman harus ditambahkan dengan titik pemesanan kembali. Sehingga dapat dihitung sebagai berikut:

$$
R O P^{*}=\text { Permintaan yang diharapkan selama waktu tunggu }+ \text { Persediaan Pengaman }
$$

Keterangan:

$R O P^{*}=$ Reorder point dengan Safety stock

Permintaan per hari (d) dapat dihitung dengan cara sebagai berikut:

$$
d=\frac{D}{\text { Jumlah hari kerja dalam satu tahun }}
$$

Keterangan:

$\mathrm{D}=$ Permintaan tahunan

\section{Kelancaran Proses Produksi}

Setiap perusahaan pasti menginginkan perusahaannya berhasil dan menghasilkan produk yang unggul dan dapat diterima oleh masyarakat. Hal tersebut akan berhasil jika perusahaan mampu meningkatkan produktivitas dalam perusahaannya pada setiap tahunnya.

Fahmi (2014) menyatakan bahwa kelancaran proses produksi dapat dilihat dari jumlah unit yang dihasilkan, kecepatan waktu yang mampu dihasilkan, dan kualitas produk yang sesuai dengan standar. Sedangkan menurut Assauri (2015) bahwa Kelancaran proses produksi adalah sesuatu yang diinginkan dan didambakan oleh setiap perusahaan terutama perusahaan yang bergerak dibidang industri.

\section{$3 \quad$ Metodologi Penelitian}

Pada penelitian ini menggunakan data kualitatif. Pengolahan data secara kualitatif untuk mengolah data berupa rencana dan realisasi kuantitas bahan baku rotan untuk pembuatan keranjang/bucket dari tahun 2014 sampai dengan tahun 2018. 


\section{Hasil Penelitian dan Pembahasan}

\section{Pengendalian Persediaan Bahan Baku Rotan Pada CV. Home Fashions Indonesia Cirebon}

CV. Home Fashions Indonesia bergerak dalam bidang industri furniture rotan, kayu dan anyaman Hasil produksi tersebut lalu disalurkan ke seluruh wilayah Republik Indonesia bahkan sampai diekspor ke luar negeri. Tenaga kerja yang dimiliki oleh perusahaan sebanyak 17 orang, rata-rata berasal dari Cirebon. .dalam penelitian. Dalam hal ini penulis hanya membahas pengendalian persediaan bahan baku berdasarkan kebijakan perusahaan dengan berdasarkan metode Economic Order Quantity, serta pada proses produksi.

Adapun data perusahaan yang menunjukkan pada tahun 2014 frekuensi pemesanan sebanyak 6 kali dengan permintaan sebesar $95.297 \mathrm{~kg}$ dan rata-rata pembelian sebesar $15.883 \mathrm{~kg}$, pada tahun 2015 frekuensi pemesanan sebanyak 6 kali dengan dengan permintaan sebesar $105.195 \mathrm{~kg}$ serta rata-rata pembelian sebesar $17.533 \mathrm{~kg}$, dan untuk tahun 2016 frekuensi pemesanan bahan baku terjadi sebanyak 6 kali dengan pemesanan sebesar $110.125 \mathrm{~kg}$ serta rata-rata pembelian bahan baku sebesar $18.354 \mathrm{~kg}$, sedangkan untuk tahun 2017 frekuensi pemesanan tahun sebelumnya biasanya terjadi sebanyak 6 kali, namun pada tahun 2017 ditambah menjadi 7 kali, hal ini karena jumlah pemesanan produk dari Eropa cukup meningkat sehingga harus menambah jumlah frekuensi pembelian bahan baku dengan pemesanan $113.100 \mathrm{~kg}$ dan jumlah rata-rata pembelian sebesar $16.157 \mathrm{~kg}$, pada tahun 2018 dengan frekuensi pembelian bahan baku sebanyak 6 kali dan pembelian bahan baku sebesar $106.475 \mathrm{~kg}$ dengan rata-rata pembelian sebesar $17.746 \mathrm{~kg}$.

Setelah menggunakan metode Economic Order Quantity dalam pengendalian persediaan bahan baku rotan maka terdapat hasil sebagai berikut untuk tahun 2016 jika menggunakan suatu metode dalam menentukan pemesanan persediaan bahan baku dalam setiap kali pembelian akan lebih ekonomis yaitu sebesar $31.524 \mathrm{~kg}$, dengan frekuensi pembelian sebanyak 4 kali karena pada tahun 2016 permintaan produk cukup tinggi, dengan total biaya persediaan sebesar Rp. 94.572.000, dan untuk titik pemesanan kembali dengan persediaan pengaman sebesar $2.936 \mathrm{~kg}$. Sedangkan untuk tahun 2017 pemesanan dalam setiap kali pembelian bahan baku dengan menggunakan suatu metode akan lebih ekonomis sebesar $32.830 \mathrm{~kg}$, dengan frekuensi pembelian bahan baku sebanyak 3 kali, dengan total biaya persediaan sebesar Rp. 102.593.00, serta titik pemesanan kembali dengan persediaan pengaman sebesar $3.016 \mathrm{~kg}$. Selain itu untuk tahun 2018 bahan baku dalam setiap kali pembelian sebesar $30.823 \mathrm{~kg}$, dengan frekuensi pembelian sebanyak 4 kali untuk memenuhi target permintaan bahan baku, dengan total biaya persediaan sebesar Rp. 100.176.000, dan titik pemesanan kembali dengan persediaan pengaman sebesar $2.840 \mathrm{~kg}$.

Adapun penghitungan total biaya persediaan yang dilakukan berdasarkan kebijakan perusahaan dan berdasarkan kebijakan Economic Order Quantity dalam tabel 1, sebagai berikut:

Tabel 1: Total biaya persediaan menurut kebijakan perusahaan dan menurut Economic Order Quantity Tahun 2014-2018

\begin{tabular}{|c|c|c|c|c|c|c|c|}
\hline Tahun & Keb & jakan Perusahaan & & bijakan EOQ & & Selisih & $\%$ \\
\hline 2014 & $\mathrm{Rp}$ & 83.004 .000 & $\mathrm{Rp}$ & 65.302 .000 & $\mathrm{Rp}$ & 17.702 .000 & $21 \%$ \\
\hline 2015 & $\mathrm{Rp}$ & 92.463 .000 & $\mathrm{Rp}$ & 74.174 .000 & $\mathrm{Rp}$ & 18.289 .000 & $20 \%$ \\
\hline 2016 & $\mathrm{Rp}$ & 108.748 .000 & $\mathrm{Rp}$ & 94.572 .000 & $\mathrm{Rp}$ & 14.176 .000 & $13 \%$ \\
\hline 2017 & $\mathrm{Rp}$ & 129.476 .000 & $\mathrm{Rp}$ & 102.593 .000 & $\mathrm{Rp}$ & 26.883 .000 & $21 \%$ \\
\hline 2018 & $\mathrm{Rp}$ & 115.836 .000 & $\mathrm{Rp}$ & 100.176 .000 & $\mathrm{Rp}$ & 15.660 .000 & $14 \%$ \\
\hline
\end{tabular}


Data di atas menunjukkan bahwa pada tahun 2014 total biaya persediaan berdasarkan kebijakan perusahaan yaitu Rp. 83.004.000 sedangkan total biaya persediaan berdasarkan metode Economic Order Quantity yaitu Rp. 65.302.000. Pada tahun 2015 total biaya persediaan berdasarkan kebijakan perusahaan yaitu Rp. 92.463 .000 sedangkan total biaya persediaan berdasarkan metode Economic Order Quantity yaitu Rp. 74.174.000. Untuk tahun 2016 total biaya pemesanan berdasarkan kebijakan perusahaan sebesar Rp. 108.748.000 sedangkan total biaya pemesanan berdasarkan metode Economic Order Quantity sebesar Rp. 94.572.000. Adapun untuk tahun 2017 total biaya persediaan sebesar Rp. 129.476.000 sedangkan total biaya persediaan berdasarkan metode Economic Order Quantity sebesar Rp. 102.593.000. Dan untuk tahun 2018 total biaya persediaan sebesar Rp. 115.836.000 sedangkan total biaya persediaan berdasarkan metode Economic Order Quantity sebesar Rp. 100.176.000.

Berdasarkan pembahasan di atas, apabila CV. Home Fashions Indonesia Cirebon menggunakan metode Economic Order Quantity dalam menentukan jumlah pembelian yang optimal dan ekonomis akan lebih terstruktur, karena jumlah pembelian bahan bahan akan dipastikan konstan.

\section{Kelancaran Proses Produksi Pada CV. Home Fashions Indonesia Cirebon}

Kelancaran proses produksi pada CV. Home Fashions Indonesia selalu ada kendala yang bermacam-macam, kendala yang dihadapi biasanya terjadi pada bahan baku itu sendiri, pada saat kekurangan ataupun bahan baku tidak layak pakai dan mesin juga rusak, sehingga hal tersebut dapat menyebabkan terhambatnya kelancaran produksi.

Adapun target produk yang dihasilkan oleh perusahaan untuk setiap tahunnya sebanyak 40.000 pcs. Perusahaan menetapkan kebijakan bahwa untuk pencapaian produksi sebesar 50\%-100\%. Berikut data pencapaian produksi pada CV. Home Fashions Indonesia Cirebon selama tahun 2014-2018 dalam Tabel 2, yaitu:

Tabel 2: Jumlah pencapaian proses produksi selama Tahun 2014-2018

\begin{tabular}{cccc}
\hline Tahun & Target Produksi (Pes) & $\begin{array}{c}\text { Jumlah Pencapaian } \\
\text { Produksi (Pcs }\end{array}$ & \% \\
\hline $\mathbf{2 0 1 4}$ & 40.000 & 28.589 & $71 \%$ \\
\hline $\mathbf{2 0 1 5}$ & 40.000 & 31.559 & $79 \%$ \\
\hline $\mathbf{2 0 1 6}$ & 40.000 & 33.038 & $83 \%$ \\
\hline $\mathbf{2 0 1 7}$ & 40.000 & 33.930 & $85 \%$ \\
\hline $\mathbf{2 0 1 8}$ & 40.000 & 31.943 & $80 \%$ \\
\hline
\end{tabular}

Berdasarkan tabel di atas untuk tahun 2014-2018 perusahaan menargetkan produk yang dihasilkan setiap tahunnya sebanyak 40.000 pcs. Untuk tahun 2014 produk yang dihasilkan sebanyak 28.589 pcs yaitu $71 \%$, untuk tahun 2015 produk yang dihasilkan sebanyak 31.559 pcs dengan pencapaian produksi sebesar 79\%, untuk tahun 2016 produk yang dihasilkan sebanyak 33.038 pcs dengan persentase $83 \%$, tahun 2017 perusahaan menghasilkan produk sebanyak 33.930 pcs dengan persentase $85 \%$, dan untuk tahun 2018 produk yang dihasilkan sebanyak 31.943 pcs dengan persentase $80 \%$.

Sedangkan penghitungan pencapaian produksi berdasarkan hasil penghitungan Economic Order Quantity dapat dilihat pada Tabel 3 di bawah ini: 
Tabel 3: Pencapaian produksi menurut Economic Order Quantity

\begin{tabular}{cccc}
\hline Tahun & $\begin{array}{c}\text { Target Produksi } \\
(\text { Pcs })\end{array}$ & $\begin{array}{c}\text { Jumlah Pencapaian } \\
\text { Produksi (Pcs) }\end{array}$ & Persentase \\
\hline $\mathbf{2 0 1 4}$ & 40.000 & 29.386 & $73 \%$ \\
\hline $\mathbf{2 0 1 5}$ & 40.000 & 31.415 & $79 \%$ \\
\hline $\mathbf{2 0 1 6}$ & 40.000 & 37.829 & $95 \%$ \\
\hline $\mathbf{2 0 1 7}$ & 40.000 & 29.548 & $74 \%$ \\
\hline $\mathbf{2 0 1 8}$ & 40.000 & 36.988 & $92 \%$ \\
\hline
\end{tabular}

Data di atas menunjukkan bahwa target pencapaian produksi pada CV. Home Fashions Indonesia dapat dikatakan berhasil. Karena pada tahun 2014 pencapaian produksi sebesar 73\%, tahun 2015 mencapai 79\%, untuk tahun 2016 pencapaian produksi sebesar 95\%, pada tahun 2017 mencapai 74\%, dan untuk tahun 2018 mencapai 92\%.

Hal tersebut dapat dilihat bahwa pencapaian produksi dengan penghitungan produksi menggunakan metode Economic Order Quantity akan lebih besar dibandingkan dengan pencapaian produksi berdasarkan kebijakan perusahaan.

Perusahaan menetapkan untuk kelancaran proses produksi berdasarkan target waktu produksi sebesar $21 \%-40 \%$, hal ini karena didalam proses produksi tentunya ada kendala-kendala yang terjadi, seperti ada dan tidaknya bahan baku.

Berikut hasil pencapaian produksi yang dihasilkan selama 2014-2018 pada CV. Home Fashions Indonesia disajikan dalam Tabel 4, sebagai berikut:

Tabel 4: Target waktu produksi

\begin{tabular}{cccc}
\hline Tahun & Jumlah Pencapaian Produksi (Pcs) & Waktu Produksi (Menit) & Persentase \\
\hline $\mathbf{2 0 1 4}$ & 28.589 & 144.000 & $20 \%$ \\
\hline $\mathbf{2 0 1 5}$ & 31.559 & 144.000 & $21 \%$ \\
\hline $\mathbf{2 0 1 6}$ & 33.038 & 144.000 & $23 \%$ \\
\hline $\mathbf{2 0 1 7}$ & 33.930 & 144.000 & $23 \%$ \\
\hline $\mathbf{2 0 1 8}$ & 31.943 & 144.000 & $22 \%$ \\
\hline
\end{tabular}

Berdasarkan tabel di atas untuk tahun 2014-2018 dengan target waktu produksi 300 hari atau setara dengan 144.000 menit. Untuk tahun 2014 produk yang dihasilkan sebanyak 28.589 pcs yaitu 20\%, untuk tahun 2015 produk yang dihasilkan sebanyak 31.559 pcs dengan persentase $21 \%$, untuk tahun 2016 produk yang dihasilkan sebanyak 33.038 pcs dengan persentase $23 \%$, tahun 2017 perusahaan menghasilkan produk sebanyak 33.930 pcs dengan persentase $23 \%$, dan untuk tahun 2018 produk yang dihasilkan sebanyak 31.943 pcs dengan persentase $22 \%$. Sedangkan menurut perhitungan Economic Order Quantity dapat dilihat pada tabel 5 di bawah ini: 
Tabel 5: Jumlah pencapaian proses produksi menurut Economic Order Quantity

\begin{tabular}{cccc}
\hline Tahun & Jumlah Pencapaian Produksi (Pcs) & Waktu Produksi (Menit) & \% \\
\hline $\mathbf{2 0 1 4}$ & 29.900 & 144.000 & $21 \%$ \\
\hline $\mathbf{2 0 1 5}$ & 31.415 & 144.000 & $22 \%$ \\
\hline $\mathbf{2 0 1 6}$ & 37.829 & 144.000 & $26 \%$ \\
\hline $\mathbf{2 0 1 7}$ & 29.548 & 144.000 & $21 \%$ \\
\hline $\mathbf{2 0 1 8}$ & 36.988 & 144.000 & $26 \%$ \\
\hline
\end{tabular}

Berdasarkan tabel di atas pada tahun pada tahun 2014-2018 dengan target waktu produksi yang sama, untuk tahun 2014 menurut Economic Order Quantity menghasilkan produksi sebanyak 29.386 pcs yaitu sebesar $20 \%$, untuk tahun 2015 menghasilkan pencapaian produksi sebanyak 31.415 pcs yaitu $22 \%$, tahun 2016 jumlah pencapaian produksi sebanyak 37.829 pcs yaitu $26 \%$, untuk tahun 2017 produk yang dihasilkan 29.548 pcs yaitu $26 \%$.

Berdasarkan hasil di atas bahwa kelancaran pada proses produksi yang dilakukan oleh CV. Home Fashions Indonesia Cirebon berdasarkan tingkat persentase kelancaran yang telah ditetapkan oleh perusahaan yaitu sebesar 50 \%-100 \% berdasarkan pencapaian produksi bahwa pada tahun 20142018 dapat dikatakan lancar karena mencapai target. Dan berdasarkan tingkat persentase target waktu produksi yang ditentukan oleh perusahaan yaitu 21\%-40\%, pada tahun 2014 dikatakan tidak lancar karena tingkat persentase pencapaian produksi berdasarkan target waktu produksi hanya mencapai 20\% tidak sesuai dengan kebijakan perusahaan. Tetapi untuk tahun 2015-2018 dikatakan lancar karena mencapai target yang telah ditetapkan.

\section{Pengendalian Persediaan Bahan Baku Terhadap Kelancaran Proses Produksi}

Berdasarkan wawancara di CV. Home Fashions Indonesia Cirebon saat ini belum terstruktur dan stabil, terlihat bahwa kurangnya pengendalian tentunya akan berpengaruh pada kualitas bahan baku, dan masih juga terjadi kekurangan dan kelebihan bahan baku. Hal ini dapat dilihat pada pengendalian persediaan bahan baku menurut perusahaan yang dilihat dari biaya pembelian, biaya pemesanan, biaya penyimpanan.

Berdasarkan penelitian pada CV. Home Fashions Indonesia pengendalian persediaan bahan baku berdasarkan wawancara bahwa perusahaan belum mampu menentukan jumlah pembelian yang optimal dan ekonomis, dan dalam pengadaan bahan baku belum stabil, terkadang terjadi kekurangan dan kelebihan setiap tahunnya. Pada saat pembelian yang dilakukan karena terjadi kekurangan bahan baku, perusahaan harus melakukan pembelian secara terus menerus. Hal ini berdasarkan informan bahwa untuk pemesanan dalam satu tahun terkadang berbeda-beda. Kalau memang di dalam perusahaan mengalami kekurangan pembelian dapat dilakukan sebanyak 6-7 kali, hal ini dapat menimbulkan biaya-biaya yang lebih besar karena pembelian secara terus menerus dan biaya pengiriman serta akan menghambat proses produksi.

Dalam hal ini dengan metode yang tepat untuk mengoptimalkan bahan baku dan meminimalkan biaya-biaya dapat menggunakan metode Economic Order Quantity. Karena dengan menggunakan metode ini dapat menentukan jumlah yang optimal, juga dapat meminimumkan biaya persediaan dalam proses produksi.

Penghitungan dengan metode Economic Order Quantity dapat membantu perusahaan dalam pembelian bahan baku. Frekuensi pembelian yang dilakukan lebih sedikit dibandingkan dengan kebijakan yang selama ini dilakukan oleh perusahaan, dan total persediaan dengan menggunakan 
Economic Order Quantity lebih hemat dibandingkan dengan total persediaan yang dikeluarkan perusahaan, sehingga dengan adanya frekuensi yang sedikit juga dapat menekankan biaya pemesanan yang dilakukan oleh CV. Home Fashions Indonesia.

Hal tersebut dibuktikan oleh penelitian yang dilakukan oleh Khoirunnisa (2016) pada PT. Bo Kyung yang mana jumlah pembelian bahan baku untuk kelancaran proses produksi dengan menggunakan metode Economic Order Quantity lebih terstruktur, sehingga dalam pembelian biaya yang dikeluarkan oleh perusahaan lebih hemat dan tidak terjadi pemborosan.

Untuk kelancaran proses produksi yang dilakukan oleh CV. Home Fashions Indonesia berdasarkan pencapaian produksi perusahaan menetapkan kebijakan sebesar 50\%-100\%. Adapun pencapaian produksi yang dihasilkan berdasarkan target waktu cukup memadai dan tingkat persentase tiap tahunnya tercapai sesuai dengan yang ditetapkan mencapai $21 \%-35 \%$. Hal ini sesuai dengan pernyataan Assauri (2015) bahwa kelancaran proses produksi ini dapat dilihat dari pencapaian produksi dan waktu produksi yang dihasilkan, sehingga hasil dari proses produksi dapat selesai pada waktunya.

\section{$5 \quad$ Simpulan dan Saran}

Berdasarkan hasil penelitian pada CV. Home Fashions Indonesia, maka dapat disimpulkan bahwa:

1. Pengendalian persediaan bahan baku pada CV. Home Fashions Indonesia Cirebon belum menggunakan teknik atau metode apapun. Namun dengan menggunakan metode Economic Order Quantity, dapat dilihat sebagai berikut:

a) Dapat menentukan jumlah pembelian bahan baku yang optimal dan ekonomis dengan lebih terstruktur, karena jumlah pembelian bahan baku dipastikan konstan.

b) Pembelian bahan baku yang dilakukan oleh perusahaan selama tahun 2014-2018 lebih sering dilakukan dibandingkan dengan pembelian bahan baku yang dilakukan dengan menggunakan metode Economic Order Quantity. Dengan menggunakan metode Economic Order Quantity pembelian bahan baku ekonomis dan dipastikan konstan. Adapun frekuensi pembelian bahan baku yang dilakukan lebih minimal dari pada frekuensi pembelian bahan baku yang dilakukan berdasarkan kebijakan perusahaan.

c) Total biaya persediaan yang dikeluarkan oleh perusahaan selama tahun 2014-2018 lebih besar dibandingkan dengan total biaya persediaan yang dihitung dengan menggunakan metode Economic Order Quantity. Dengan menggunakan metode tersebut perusahaan dapat meminimalkan biaya persediaan yang dikeluarkan.

d) Perusahaan dapat menentukan titik pemesanan kembali dengan persediaan pengaman secara tepat, tanpa menunggu persediaan bahan baku habis.

2. Kelancaran proses produksi pada CV. Home Fashions Indonesia pada tahun 2014 dikatakan belum baik. Namun setelah menggunakan metode Economic Order Quantity proses produksi lebih lancar dan jumlah produk yang dihasilkan cukup tinggi dari sebelumnya.

3. Pengendalian persediaan bahan baku dengan menggunakan metode Economic Order Quantity dapat menentukan jumlah persediaan yang ekonomis dan konstan, perusahaan dapat menentukan titik pemesanan kembali dengan persediaan pengaman secara tepat, sehingga proses produksi akan lebih lancar dan tepat waktu. 
Berdasarkan simpulan di atas, maka saran yang dapat diberikan antara lain sebagai berikut:

1. Perusahaan sebaiknya untuk mengendalian persediaan bahan baku menggunakan teknik atau metode seperti Economic Order Quantity, karena metode ini lebih efektif dan efisien dalam menentukan jumlah pembelian bahan baku. Perusahaan juga dapat menerapkan metode ini untuk menunjang kelancaran proses produksi.

2. Peneliti selanjutnya dapat mengembangkan lagi penerapan metode Economic Order Quantity pada perusahaan lain, dan hal apa saja yang dapat dipengaruhi oleh metode ini selain kelancaran proses produksi.

\section{Daftar Pustaka}

Ahyari, Agus. (2006). Manajemen Produksi II Edisi Ke Tiga. Yogyakarta: FE.

Andira, O. E. (2016). Jurnal Ekonomi Bisnis. , Analisis Persediaan Bahan Baku Tepung Terigu Menggunakan Metode EOQ (Economic Order Quantity) Pada Roti Puncal Makasar, Volume 21 No.3.

Apriyani , N., \& Muhsin, A. (2017). Jurnal OPSI. Analisis Pengendalian Persediaan Bahan Baku Dengan Metode Economic Order Quantity dan Kanba Pada PT. Adyawinsa Stamping Indistries, Vol 10 No 2 ISSN 1693-2102.

Assauri, S. (2015). Manajemen Produksi dan Operasi. Jakarta: Lembaga Penerbit Fakultas Ekonomi Universitas Indonesia.

Carter, W. K. (2013). Akuntansi Biaya. Jakarta: Salemba Empat.

Eunike, A., Setyanto, N. W., Yuniarti, R., Hamdala, I., Lukodono, R. P., \& Fanani, A. A. (2018). Perencanaan Produksi dan Pengendalian Persediaan. Malang: UB Press.

Fahmi, I. (2014). Manajemen Produksi dan Operasi. Bandung: ALFABETA.

Fajrin, E. H., \& Slamet, A. (2016). Management Analysis Journal. Analisis Pengendalian Persediaan Bahan Baku Dengan Menggunakan Metode Economic Order Quantity (EOQ) Pada Perusahaan Roti Bonansa, Vol.5 (4) ISSN 2252-6552.

Hanafi, M. M. (2016). Manajemen Keuangan. Yogyakarta: BPFE.

Handoko, T. H. (2012). Manajemen Produksi dan Operasi. Yogyakarta: BPFE.

Heizer, J., \& Render, B. (2017). Manajemen Operasi. Jakarta: Salemba Empat.

Herjanto, E. (2014). Manajemen Operasi. Jakarta: Grasindo.

Lahu, E. P., \& Sumarauw, J. S. (2017). Jurnal EMBA. Analisis Pengendalian Persediaan Bahan Baku Guna Meminimalkan Biaya Persediaan Pada Dunkin Donuts Manado, Vol.5 No.3 Hal. 4175-4184.

Mahmudah. (2018). eJournal Administrasi Bisnis. Analisis Pengendalian Persediaan Bahan Baku Kacang Kedelai Dengan Metode Economic Order Quantity pada UD. Al Hayuun Di Samarinda, Volume 6 (4): 1814-1827 ISSN 2355-5408.

Manullang , N. (2012). Dasar-Dasar Manajemen . Yogyakarta: Gajah Mada University Press.

Nafarin, M. (2013). Penganggaran Perusahaan. Jakarta: Salemba Empat.

Naibaho, A. T. (2013). Jurnal EMBA. Analisis Pengendalian Internal Persediaan Bahan baku Terhadap Efektifitas Pengelolaan Persediaan Bahan Baku, Vol.1 No.3 Hal. 63-70.

Nissa, K., \& Siregar, M. T. (2017). International Journal of Social Science and Business. Analisis Pengendalian Persediaan Bahan Baku Kain Kemeja Poloshirt Menggunakan Metode Economic Order Quantity (ROA), Vol.1 (4) pp. 271-279.

Ristono , A. (2013). Manajemen Persediaan. Yogyakarta: Grahallmu.

Robyanto, C. B., Antara, M., \& Dewi, R. K. (2013). E-Jurnal Agribisnis dan Agrowisata. Analisis Persediaan Bahan Baku Tebu pada Pabrik Gula Pandji PT. Perkebunan Nusantara XI (Persero) Situbondo, Jawa Timur, Vol.2 No.1 ISSN: 2301-6523.

Siagian, Y. M. (2007). Aplikasi Supply Chain Management. Jakarta: Grasindo. 
Siregar, B., Suripto, B., Hapsoro, D., Lo, E. W., \& Biyanto, F. (2017). Akuntansi Manajemen. Jakarta: Salemba Empat.

Sugiyono. (2017). Metode Penelitian Kuantitatif, Kualitatif dan R\&D. Bandung: Alfabeta. 